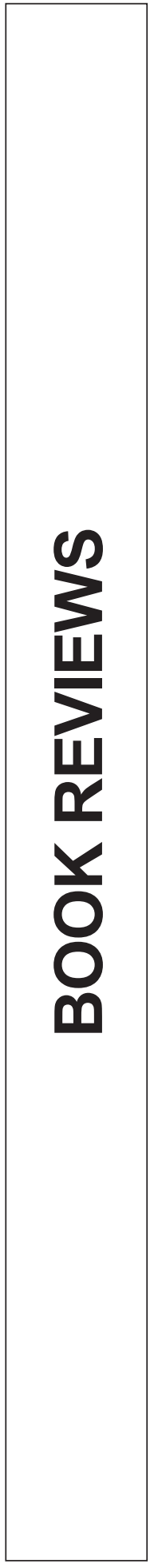



DOI : $10.14746 /$ ps.2018.1.35

\section{Badanie polityki zagranicznej państwa, Edward Haliżak (ed.), Rambler, Warszawa 2018, 590 pp, ISBN: 978-83-62751-64-8.}

Badanie polityki zagranicznej państwa is an important contribution to studies on international relations in general and on theory of foreign policy in particular. The book consists of introduction and 17 chapters. It is divided into four parts. The editor, Prof. Edward Haliżak (the University of Warsaw), managed to gather a very experienced and professional group of authors specializing in theory and practice of the contemporary foreign policy. Substantially, the book delves into difficulties which have to be overcome in studies on foreign policy analysis - FPA. Although the volume is very large and consists of 590 pages, it is justified and all chapters are logically connected.

In the introduction Edward Haliżak presents the theoretical framework as well as the main aspects of foreign policy analysis. This part focuses mainly on key research approaches and concepts dedicated to FPA. The author attempts to identify the research framework as well as key methodological assumptions. It is worth emphasizing the exceptional and in-depth analysis of the past studies. Haliżak refers to key concepts and views of such influential scholars as George Modelski, Joseph Frankel, Richard Snyder, James Rosenau, Valerie Hudson, Gunter Hellman, Walter Carlsnaess or Amelia Hadfield. He also analyses the subject of FPA, key research strategies as well as research procedures, for instance, causality, pragmatism, interdisciplinarity, multidisciplinarity, and transdisciplinarity. Hence Haliżak's chapter constitutes a very useful and informative introduction to the following four parts of the book.

The first part of the book is dedicated to methodological aspects. There are three chapters. Edward Haliżak focuses on a model approach to foreign policy, while Aldona Tomczyńska verifies theory on the basis of the economic sanctions analysis. The last chapter, written by Iwona Krzyżanowska-Skowronek, is dedicated to interpretivism in the contemporary international relations.

Compared with the first part, the following parts are increasingly detailed. The second part touches upon issues related to theory of foreign policy and consists of five chapters. Marek Pietraś focuses on foreign policy and its role in the discipline of international relations. Mirosław Sułek analyses foreign policy within power cycle theory and Magdalena Kozub-Karkut writes about FPA in international relations theory. In the last two chapters Anna Umińska-Woroniecka presents the application of theory of operational code in FPA, while Rafał Kwieciński's text is related to the Chinese response to new challenges in maritime environment in the light of neoclassical realism.

In the third part of Badanie polityki zagranicznej państwa authors analyse new research directions. A biological factor and its role in the contemporary foreign policy are described by Jerzy Ciechański. The following chapters are dedicated to diplomatic missions (Beata Surmacz), a geo-economic approach in the FPA in case of Russia (Rafał Lisiakiewicz), relations between media and foreign policy (Justyna Arendarska), and economic diplomacy (Weronika Garbacz).

The publication would be incomplete without any practical dimension. Hence the fourth part focuses on selected case studies. The first two chapters offer the review of the 
foreign policy of the Polish People's Republic (Wanda Jarząbek, Agnieszka KisztelińskaWęgrzyńska). Hanna Dumała decided to analyse initiatives of the Polish local authorities in the framework of the Polish foreign policy. The last text is related to theoretical and empirical dimensions of the EU external policy (Anna Skolimowska).

Nevertheless, a few reservations are worth putting forward. Firstly, the reviewer recommends translating the book from Polish into English. Undoubtedly, English speaking readers could only benefit from such a translation and become familiar with 'the Polish school of FPA' represented by Edward Haliżak and his associates. Secondly, the fourth part could include a few more chapters dedicated to other cases. There is, for instance, no chapter connected with the U.S. foreign policy.

Overall, the authors provide a valuable look at the field of foreign policy analysis. They convincingly reveal opportunities as well as pitfalls connected with exploring FPA in the framework of their research field. The book is recommended to scholars interested in the contemporary international relations. Undoubtedly, the authors wrote the chapters carefully and their thorough account of foreign policy analysis will become a go-to reference text for both academics and the public.

Przemysław OSIEWICZ 